\title{
Self-ligating versus conventional metallic brackets on Streptococcus mutans retention: A systematic review
}

\author{
Juliano N. Longoni ${ }^{1}$, Beatriz M. V. Lopes ${ }^{1}$, Irlan A. Freires ${ }^{2}$, Kamile L. Dutra ${ }^{3}$, \\ Ademir Franco ${ }^{4}$, Luiz R. Paranhos ${ }^{5}$
}

Correspondence: Dr. Luiz Renato Paranhos

Email: paranhos.Irp@gmail.com

\begin{abstract}
'Department of Oral Biology, University of Sacred Heart (USC - Universidade do Sagrado Coração), Bauru, Brazil

${ }^{2}$ Department of Physiological Sciences, Piracicaba Dental School, University of Campinas, Piracicaba, Brazil

${ }^{3}$ Department of Dentistry, Federal University of Santa Catarina (UFSC), Florianópolis, Brazil

${ }^{4}$ Department of Stomatology, Federal University of Paraná (UFPR), Curitiba, Brazil

${ }^{5}$ Department of Dentistry, Federal University of Sergipe (UFS), Lagarto, Brazil
\end{abstract}

\section{ABSTRACT}

Objective: The present study aimed to review the literature systematically and assess comparatively whether self-ligating metallic brackets accumulate less Streptococcus mutans biofilm than conventional metallic brackets. Material and methods: The systematic search was performed following PRISMA guidelines and registration in PROSPERO. Seven electronic databases (Google Scholar, LILACS, Open Grey, PubMed, SciELO, ScienceDirect, and Scopus) were consulted until April 2016, with no restriction of language and time of publication. Only randomized clinical studies verifying S. mutans colonization in metallic brackets (self-ligating and conventional) were included. All steps were performed independently by two operators. Results: The search resulted in 546 records obtained from the electronic databases. Additionally, 216 references obtained from the manual search of eligible articles were assessed. Finally, a total of 5 studies were included in the qualitative synthesis. In 1 study, the total bacterial count was not different among self-ligating and conventional brackets, whereas in 2 studies the amount was lower for self-ligating brackets. Regarding the specific count of S. mutans, 2 studies showed less accumulation in self-ligating than in conventional brackets. Conclusion: Based on the limited evidence, self-ligating metallic brackets accumulate less S. mutans than conventional ones. However, these findings must be interpreted in conjunction with particularities individual for each patient - such as hygiene and dietary habits, which are components of the multifactorial environment that enables S. Mutans to proliferate and keep retained in the oral cavity.

Key words: Biofilm, brackets, orthodontics, Streptococcus mutans

\begin{tabular}{|l|l|}
\hline \multicolumn{3}{|c|}{ Access this article online } \\
\hline Quick Response Code: \\
\hline
\end{tabular}

This is an open access article distributed under the terms of the Creative Commons Attribution-NonCommercial-ShareAlike 3.0 License, which allows others to remix, tweak, and build upon the work non-commercially, as long as the author is credited and the new creations are licensed under the identical terms.

For reprints contact: reprints@medknow.com

How to cite this article: Longoni JN, Lopes BM, Freires IA, Dutra KL, Franco A, Paranhos LR. Self-ligating versus conventional metallic brackets on Streptococcus mutans retention: A systematic review. Eur J Dent 2017;11:537-47.

DOI: 10.4103/ejd.ejd_132_17 


\section{INTRODUCTION}

The use of brackets during orthodontic treatment favors the retention of dental biofilm. As consequence, the patient is affected with changes in oral $\mathrm{pH}$, development of caries, ${ }^{[1-4]}$ gingivitis and periodontitis. ${ }^{[5]}$ In conventional brackets, the elastomer and its elastic degradation may contribute to the accumulation of biofilm ${ }^{[5,6]}$ when compared to metallic ligatures. Besides, the total bacterial count around the elastomer is also slightly increased. ${ }^{[7]}$ To overcome this problem, orthodontic appliances were innovated with techniques and materials, such as self-ligating brackets - which do not require metallic or elastic ligatures to maintain the position of the orthodontic wire. ${ }^{[5]}$ Oppositely, other appliances did not reveal an effective performance. The use of fluoridated elastomers shows reduction in bacterial count up to 2 weeks of treatment. However, its effect is no longer observed nearly 40 days of orthodontic treatment. ${ }^{[8]}$ Similarly, composites were developed to induce less biofilm accumulation around the bracket bonding region, decreasing the potential risk of cavitation..$^{[2,9]}$ On the other hand, the correct application of composites (without excess) depends on the clinician.

Despite suggesting that biofilm formation differs according to the type of bracket used, ${ }^{[2,10]}$ the scientific literature has no consensus affirming whether the choice of self-ligating or conventional brackets should be made to avoid the increase in biofilm formation and adhesion of Streptococcus mutans to the dental surface. ${ }^{[11,14]}$ Some authors show that the amount of biofilm is related to the type of bracket and time of treatment ${ }^{[15]}$ while others affirm that self-ligating brackets have an advantage over the conventional system in retaining a lower amount of biofilm, which would facilitate the maintenance of periodontal health in orthodontic patients. ${ }^{[5,16,17]}$ Differently, other studies suggest that self-ligating brackets provide greater bacterial accumulation when compared to the conventional appliances, ${ }^{[10,18]}$ leading to clinical uncertainty regarding the choice of orthodontic system.

The possibility of offering an orthodontic bracket system that provides less bacterial accumulation is desired by orthodontists. Based on that, the present systematic literature review aims to answer the following focused question: "Do self-ligating metallic brackets used in orthodontic treatment accumulate less S. mutans biofilm than conventional metallic brackets?"

\section{MATERIALS AND METHODS}

\section{Protocol and registration}

This systematic review followed the Preferred Reporting Items for Systematic Reviews and Meta-analyses checklist ${ }^{[19]}$ and the related Cochrane guidelines. ${ }^{[20]}$

The systematic review protocol was registered at the International Prospective Register of Systematic Reviews ${ }^{[21]}$ under the protocol number: CRD42015028002 (http://www.crd.york.ac.uk/ PROSPERO).

\section{Study design}

A systematic review of human studies was performed to compare the microbial level of $S$. mutans retention around two types of metallic bracket - conventional versus self-ligating.

\section{Eligibility criteria}

Inclusion criteria

Randomized or quasi-randomized controlled trials (RCTs) aiming to evaluate and compare the microbial level of S. mutans retention around two types of metallic bracket (conventional vs. self-ligating) were included in this study. No restriction of publication language and time were applied.

\section{Exclusion criteria}

1. Studies performed with patients younger than 11 years old

2. Studies in which patients reported the use of antibiotics or any type of drug (alcohol, cigarette)

3. Studies conducted with patients with periodontal disease

4. Reviews, case reports, letters, personal opinions, book chapters, and conference abstracts

5. Studies that used animal models

6. Studies in which the S. mutans count was not measured, and

7. Studies that did not answer the PICO (P: population, I: intervention; $\mathrm{C}$ : comparison, $\mathrm{O}$ : outcome) question.

\section{Information sources}

Individual search strategies for each of the following electronic databases were performed: LILACS, PubMed, SciELO, Science Direct, Scopus, and Google Scholar. Open Grey was searched for additional literature including that might have been missed. All searches were conducted on April 20, 2016. In addition to the electronic search, a manual search 
was performed in the reference lists of the selected articles.

\section{Search strategy}

The following Medical Subject Headings were used: "Orthodontic brackets," "orthodontic," "brackets," "oral hygiene," "oral," "hygiene," "S. mutans," and "Streptococcus." These terms were combined with Boolean operators (AND, OR). The search strategy was adapted for each database search [Table 1]. Mendeley ${ }^{\mathrm{TM}}$ Desktop 1.13.3 software (Mendeley ${ }^{\mathrm{TM}}$ Ltd., London, England) was used to remove any duplicates.

\section{Study selection}

A two-phase selection of articles was conducted. In Phase 1, two operators reviewed independently the titles and abstracts of all articles. Articles that did not follow the inclusion criteria were excluded from the study. In Phase 2, the full articles selected were independently reviewed and screened by the same reviewers. Disagreements were solved by means of discussion. When mutual agreement between the two reviewers was not reached, a third reviewer was involved to make the final decision. The final selection was always based on the full text of the article.

\section{Data items and collection process}

The following descriptive characteristics were recorded for all the articles included: Study characteristics (authors, year, country of study development, and study design), sample characteristics (size, gender, and age), intervention characteristics (bracket type, dental arch involved, and dental plaque collection technique), dental plaque sample collection (periodicity, time, tooth location, storage solution, method of analysis, and bacterial count), and outcomes. If the required data were not complete, attempts were made to contact the authors to retrieve the missing information. No other information was obtained through this procedure. All the data were collected by one operator while a second cross-checked the collected information and confirmed its accuracy. Disagreements were solved as reported previously.

\section{Risk of bias in individual studies}

The risk of bias of the selected studies was evaluated using Meta-analysis of Statistics Assessment and Review Instrument (MAStARI) critical appraisal tool. Two authors assessed independently each article regarding the potential risk of bias. The risk of bias was categorized as "low," "high," or "unclear." The first occurred when the study reached up to $49 \%$ score "yes"; the second when the study reached 50\%-69\%, and the third when the study reached more than $70 \%$. The categorization was performed by two operators supported by a third operator when necessary. ${ }^{[22]}$

\section{Table 1: Search strategy adapted for each database search}

Doogle Scholar https://scholar.google.com.br

LILACS

http://lilacs.bvsalud.org

OpenGrey

http://www.opengrey.eu

PubMed http://www.ncbi.nlm.nih.gov/PubMed

\section{SCIELO}

http://www.scielo.org/

ScienceDirect https://www.sciencedirect.com

Scopus

http://www.scopus.com

Search strategy (April, 2016)

"orthodontic brackets" AND "streptococcus mutans" AND "oral hygiene" "orthodontic brackets" AND "biofilms" AND "oral hygiene"

(orthodontic brackets AND streptococcus mutans)

AND (instance:"regional") AND ( db:("LILACS"))

(orthodontic brackets AND biofilms) AND (instance:"regional”) AND (db:(“LILACS”)) (orthodontic brackets AND oral hygiene) AND (instance:"regional”) AND (db:(“LILACS”)) "orthodontic brackets"

((“orthodontic brackets"[MeSH Terms] OR ("orthodontic"[All Fields] AND "brackets"[All Fields]) OR "orthodontic brackets"[All Fields]) AND ("biofilms"[MeSH Terms] OR "biofilms"[All Fields])

(("orthodontic brackets"[MeSH Terms] OR ("orthodontic"[All Fields] AND "brackets"[All Fields]) OR "orthodontic brackets"[All Fields]) AND ("biofilms"[MeSH Terms] OR "biofilms"[All Fields])) AND ("oral hygiene"[MeSH Terms] OR ("oral"[All Fields] AND "hygiene"[All Fields]) OR "oral hygiene"[All Fields]) (("orthodontic brackets"[MeSH Terms] OR ("orthodontic"[All Fields] AND "brackets"[All Fields]) OR "orthodontic brackets"[All Fields]) AND ("streptococcus mutans"[MeSH Terms] OR ("streptococcus"[All Fields] AND "mutans"[All Fields]) OR "streptococcus mutans"[All Fields])) AND ("oral hygiene"[MeSH Terms] OR ("oral"[All Fields] AND "hygiene"[All Fields]) OR "oral hygiene"[All Fields]) "orthodontic brackets" AND "streptococcus mutans" "orthodontic brackets" AND "oral hygiene" "orthodontic brackets" AND "biofilms" AND "streptococcus mutans" AND "oral hygiene" "orthodontic brackets" AND "streptococcus mutans" AND "oral hygiene" "orthodontic brackets" AND "streptococcus mutans" AND "oral hygiene" "orthodontic brackets" AND "biofilms" AND "oral hygiene" 


\section{Summary measures}

The microbial levels of $S$. mutans retention around the two types of metallic brackets (conventional vs. self-ligating) were considered as the main outcome.

\section{SYNTHESIS OF RESULTS}

The studies were analyzed regarding the levels of bacterial count and the types of metallic bracket. The synthesis of descriptive data was provided. A meta-analysis was planned in case of homogeneity of the data collected from the included articles.

\section{Risk of bias across studies}

The heterogeneity of the studies was analyzed by comparing the variability among the characteristics of participants, type of interventions, and study outcomes. Methodological heterogeneity was calculated by comparing the variability in study design and risk of bias. Statistical heterogeneity was determined by comparing the variability of intervention effects on the articles included in this study.

Confidence in cumulative evidence

A summary of the overall strength of evidence available was presented through the tables of
"Grading of Recommendations Assessment, Development and Evaluation" (GRADE) Summary of Findings. ${ }^{[23]}$

\section{RESULTS}

\section{Study selection}

The search performed in the seven electronic databases resulted in 546 records. After removing duplicates, 331 studies remained for systematic reading of titles and abstracts. From these, 278 had no direct relation with the main outcome of the present research, 9 were literature reviews, 4 were case reports, 25 were books or book chapters, 4 were indexes, and 3 were letters to the editor. In this screening phase, only 7 articles remained for full reading. An additional article was included after searching manually the reference lists of the studies initially selected. The full text of the 8 eligible articles were read, from which 3 were excluded from the study [Appendix 1]. Finally, 5 studies were included in the final qualitative systematic synthesis. A flowchart summarizing this process of identification, inclusion, and exclusion of studies is shown in Figure 1.

\section{Study characteristics}

Three quasi-randomized split-mouth trials (quasi-RCTs), ${ }^{[13,16,17]}$ one quasi-RCT, ${ }^{[14]}$ and one $\mathrm{RCT}^{[15]}$

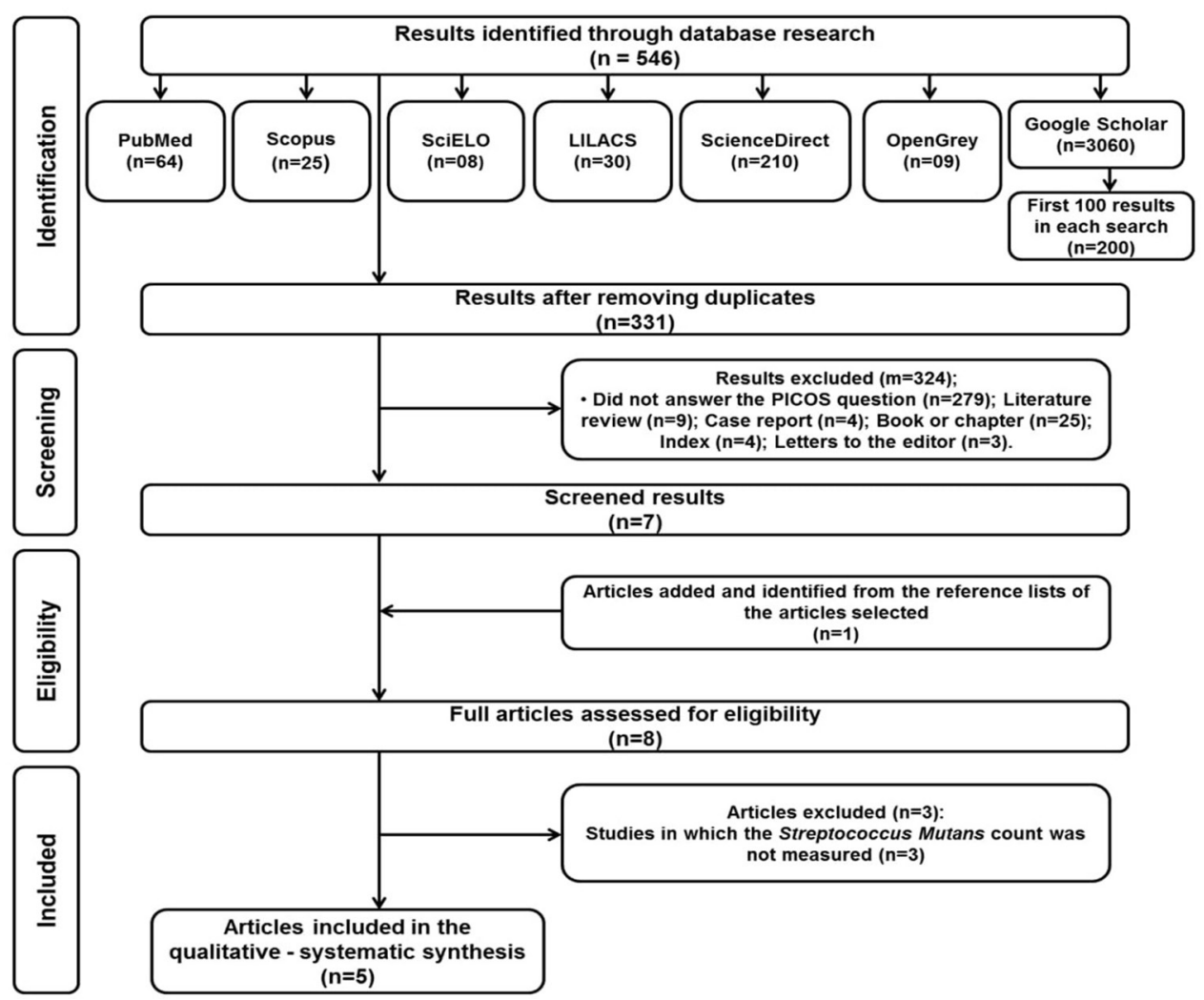

Figure 1: Flowchart of the literature search and selection criteria adapted from Preferred Reporting Items for Systematic Reviews and Meta-analyses 
were included. The research subjects included in the samples were aged between 11 and 23 years old. The ligatures of conventional brackets consisted of elastomer ${ }^{[14,15,17]}$ and steel systems. ${ }^{[13,16]}$ In all studies, the brackets were examined before and after bonding, ranging from 3 to 24 weeks. Two articles used self-ligating brackets in passive systems, ${ }^{[14,15]}$ while three articles used these brackets in active

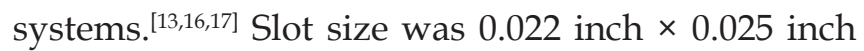
for self-ligating and conventional brackets in two articles. ${ }^{[13,14]}$ One article used self-ligating brackets of 0.022 inch and conventional brackets of 0.018 inch $\times 0.025$ inch. ${ }^{[15]}$ The other articles did not provide information on slot size. ${ }^{[16,17]}$ Storage solution and type of analysis were specific in each study. Further details are displayed in Table 1.

\section{Risk of bias within studies}

None of the included articles fulfilled all methodological quality criteria. Two of these articles presented a moderate risk of bias and 3 a low risk of bias scored according to MAStARI checklist. ${ }^{[22]}$ Detailed information about the risk of bias of studies included is found in Figures 2 and 3 and Appendix 2.

\section{Results of individual studies}

The total bacterial count and the specific S. mutans count measured in saliva through colony-forming units $(\mathrm{CFU} / \mathrm{ml})$ revealed no significant difference between self-ligating brackets and conventional brackets. ${ }^{[14]}$ Bacterial adenosine triphosphate measured by the release of visible light showed less oral bacterial retention, including $S$. mutans in self-ligating brackets. ${ }^{[17]}$ The measurement by $\mathrm{CFU} / \mathrm{ml}$ showed less activity of bacterial colonization in self-ligating appliances. ${ }^{[16]}$ Specific $S$. mutans count analyzed by the DNA extracted through real-time polymerase chain reaction (PCR) showed that self-ligating and conventional brackets with steel ligatures presented similar pattern in the number of microorganisms. ${ }^{[13]}$

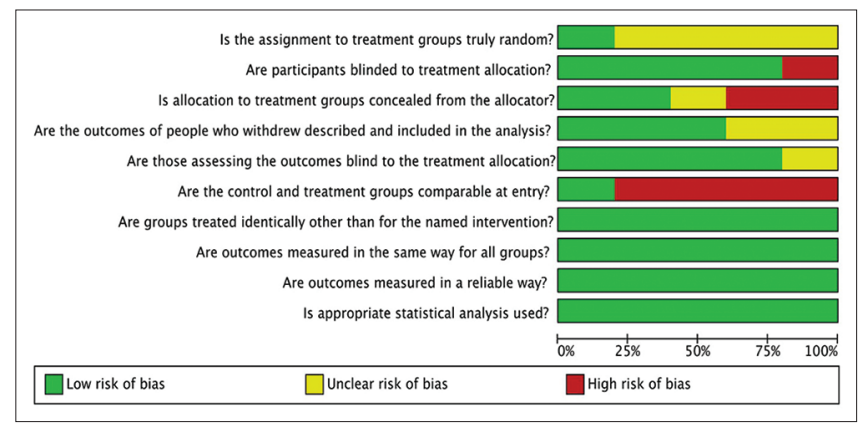

Figure 2: Risk of bias scored according to Meta-analysis of Statistics Assessment and Review Instrument checklist
The measurement by $\mathrm{CFU} / \mathrm{ml}$ in saliva showed that the quantification of bacteria in the beginning of treatment is not the same during treatment, showing different tendencies according to the type of bracket and period analyzed..$^{[15]}$

\section{Synthesis of results}

The parameter of the total bacterial count was an important comparative approach performed in 3 of the studies selected..$^{[14,16,17]}$ One study ${ }^{[14]}$ did not find significant differences in the total bacterial count between conventional brackets $(\mathrm{T} 0=6.78 \pm$ 1.79 and $\mathrm{T} 1=7.76 \pm 1.32)$ and self-ligating brackets $(\mathrm{T} 0$ and $\mathrm{T} 1=7.24 \pm 2.09)$. Another study ${ }^{[16]}$ showed less bacterial colonization, in all periods assessed, in self-ligating brackets $(\mathrm{T} 0=5.91 \pm 0.38, \mathrm{~T} 1=6.71$ $\pm 0.39, \mathrm{~T} 2=6.91 \pm 0.38, \mathrm{~T} 3=7.91 \pm 0.38$, and $\mathrm{T} 4=$ $7.70 \pm 0.38)$ than in conventional brackets $(\mathrm{T} 0=5.81$ $\pm 0.36, \mathrm{~T} 1=7.81 \pm 0.36, \mathrm{~T} 2=7.91 \pm 0.41, \mathrm{~T} 3=8.51 \pm$ 0.39 , and $\mathrm{T} 4=8.41 \pm 0.39)$. Other studies ${ }^{[17]}$ showed less bacterial retention in self-ligating brackets $(\mathrm{T} 1=2.00 \pm 2.46$ and $\mathrm{T} 2=2.00 \pm 4.23)$ than in

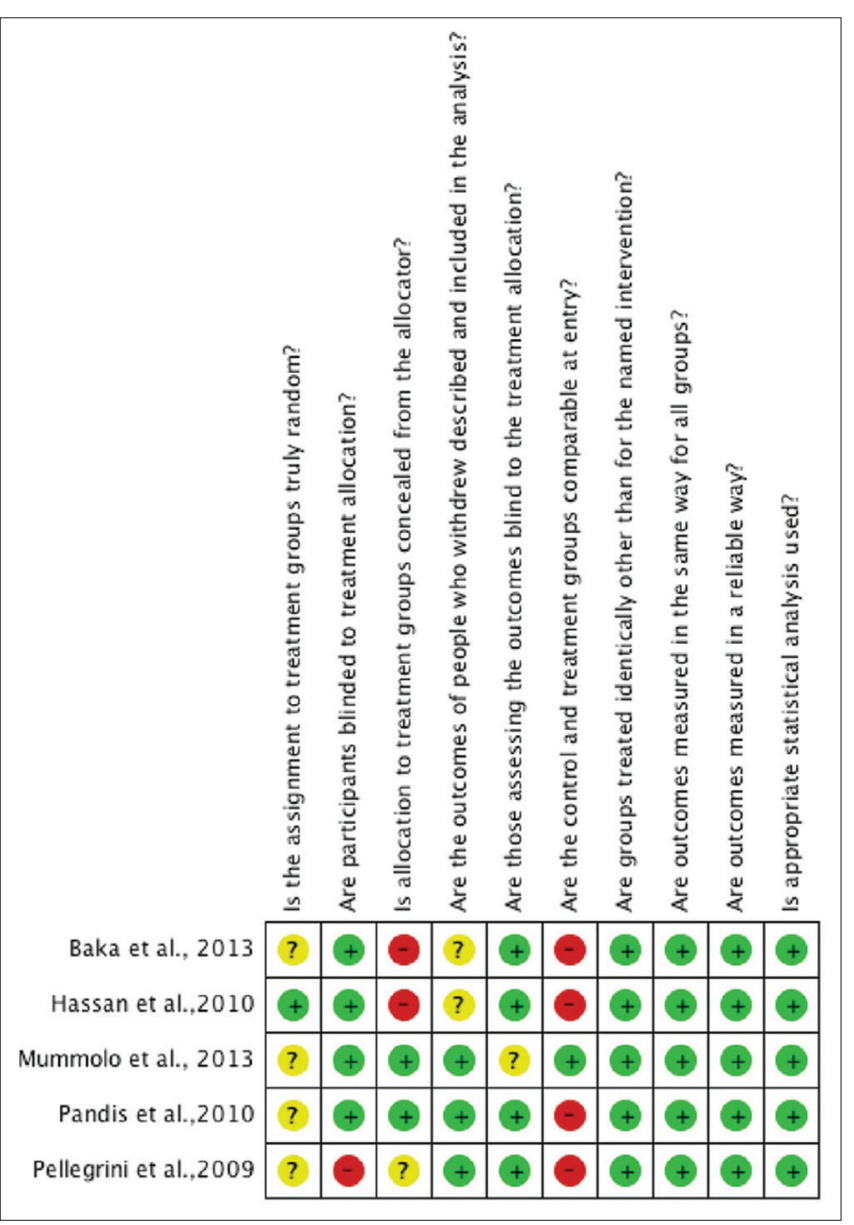

Figure 3: Summary of the risk of bias scored according to Meta-analysis of Statistics Assessment and Review Instrument checklist as (+) YES; (-) $\mathrm{NO}$; (?) unclear 
Table 2: Total Streptococcus count according to the time spent with brackets

\begin{tabular}{|c|c|c|c|c|c|c|c|c|c|c|}
\hline \multirow[t]{4}{*}{ Author (year) } & \multicolumn{10}{|c|}{ Count** } \\
\hline & \multicolumn{10}{|c|}{ Total } \\
\hline & \multicolumn{5}{|c|}{ Conventional } & \multicolumn{5}{|c|}{ Self-ligating } \\
\hline & TO & T1 & T2 & T3 & T4 & TO & T1 & T2 & T3 & T4 \\
\hline Pandis et al., 2009[14] & $6.78 \pm 1.79$ & $7.76 \pm 1.32$ & - & - & - & $7.24 \pm 2.09$ & $7.24 \pm 2.09$ & - & - & - \\
\hline Pellegrini et al., 2009 & - & $5.00 \pm 7.59$ & $3.00 \pm 4.68$ & - & - & - & $2.00 \pm 2.46$ & $2.00 \pm 4.23$ & - & - \\
\hline Hassan et al., 2010[16] & $5.81 \pm 0.36$ & $7.81 \pm 0.36$ & $7.91 \pm 0.41$ & $8.51 \pm 0.39$ & $8.41 \pm 0.39$ & $5.91 \pm 0.38$ & $6.71 \pm 0.39$ & $6.91 \pm 0.38$ & $7.91 \pm 0.38$ & $7.70 \pm 0$ \\
\hline
\end{tabular}

Baka et al., 2013 $3^{[13]}$

Mummolo et al., 2013 ${ }^{[15]}$

\begin{tabular}{|c|c|c|c|c|c|c|c|c|c|c|}
\hline \multirow{4}{*}{$\begin{array}{l}\text { Author } \\
\text { (year) }\end{array}$} & \multicolumn{10}{|c|}{ Count** } \\
\hline & \multicolumn{10}{|c|}{ Streptococcus } \\
\hline & \multicolumn{5}{|c|}{ Conventional } & \multicolumn{5}{|c|}{ Self-ligating } \\
\hline & TO & T1 & T2 & T3 & T4 & TO & T1 & T2 & T3 & T4 \\
\hline
\end{tabular}

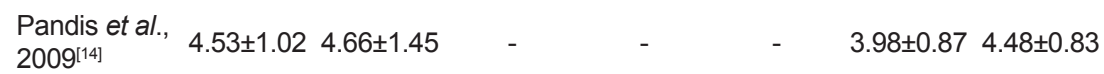

\begin{tabular}{|c|c|c|c|c|c|c|c|c|c|c|c|}
\hline $2009^{[14]}$ & $4.53 \pm 1.02$ & $4.00 \pm 1.45$ & & - & - & $3.98 \pm 0.81$ & $4.48 \pm 0.83$ & & - & - & $\begin{array}{l}\text { change the levels } \\
\text { of Streptococcus } \\
\text { mutans }\end{array}$ \\
\hline $\begin{array}{l}\text { Pellegrini } \\
\text { et al., 2009 }\end{array}$ & - & $2.00 \pm 4.02$ & $2.00 \pm 4.05$ & - & - & - & $0.70 \pm 1.17$ & $0.50 \pm 1.37$ & - & - & $\begin{array}{l}\text { Self-ligating } \\
\text { appliances provide } \\
\text { less oral bacterial } \\
\text { retention, including } \\
\text { Streptococcus }\end{array}$ \\
\hline $\begin{array}{l}\text { Hassan } \\
\text { et al., 2010[16] }\end{array}$ & $5.81 \pm 0.46$ & $6.81 \pm 0.46$ & $6.91 \pm 0.41$ & $7.51 \pm 0.49$ & $7.51 \pm 0.49$ & $5.71 \pm 0.41$ & $5.91 \pm 0.39$ & $6.01 \pm 0.38$ & $6.21 \pm 0.48$ & $6.21 \pm 0.48$ & $\begin{array}{l}\text { Self-ligating } \\
\text { appliances showed } \\
\text { less bacterial } \\
\text { colonization activity }\end{array}$ \\
\hline $\begin{array}{l}\text { Baka et al., } \\
2013^{[13]}\end{array}$ & $4.55 \pm 1.21$ & * & $6.39 \pm 1.00$ & - & - & $4.44 \pm 0.94$ & * & $6.15 \pm 1.05$ & - & - & $\begin{array}{l}\text { Self-ligating and } \\
\text { conventional } \\
\text { brackets with steel } \\
\text { ligatures presented } \\
\text { similar changes } \\
\text { in the number of } \\
\text { microorganisms, } \\
\text { with no statistically } \\
\text { significant } \\
\text { differences }\end{array}$ \\
\hline $\begin{array}{l}\text { Mummolo } \\
\text { et al., 2013 }\end{array}$ & $0^{\star * *}$ & $60^{* * *}$ & $20^{* * *}$ & - & - & $0^{* * *}$ & $25^{\star \star \star}$ & $45^{\star \star \star}$ & - & - & $\begin{array}{l}\text { Bacterial } \\
\text { quantification from } \\
\text { the beginning of } \\
\text { the treatment is not } \\
\text { the same during } \\
\text { treatment, showing } \\
\text { different tendencies } \\
\text { according to the } \\
\text { type of bracket and } \\
\text { period analyzed }\end{array}$ \\
\hline
\end{tabular}

conventional brackets $(\mathrm{T} 1=5.00 \pm 7.59$ and $\mathrm{T} 2=$ $3.0 \pm 4.68)$. Besides this parameter, 5 studies $^{[13-17]}$ observed Streptococcus count, and one study ${ }^{[15]}$ also used a control group with no use of brackets during the research $(\mathrm{T} 0=0 \%, \mathrm{~T} 1=5 \%$, and $\mathrm{T} 2=35 \%)$. The synthesis of periods and results found is described in detail in Table 2.

\section{Confidence in cumulative evidence}

The assessment of studies followed the methodological criteria of quality proposed by the GRADE method to achieve its respective scores. There were similarities in results, wherein 2 articles obtained "high" general qualification of evidence and 3 articles obtained "moderate" qualification, as described in Table 3. 


\begin{tabular}{|c|c|c|c|c|c|c|c|c|c|}
\hline \multirow[t]{3}{*}{ Authors } & \multicolumn{9}{|c|}{ Grade factors } \\
\hline & \multicolumn{6}{|c|}{ Quality assessment } & \multicolumn{3}{|c|}{ Summary of results } \\
\hline & $\begin{array}{l}\text { Study } \\
\text { design }\end{array}$ & $\begin{array}{l}\text { Study } \\
\text { limitations }\end{array}$ & Inconsistency & $\begin{array}{l}\text { Lack of } \\
\text { objectivity }\end{array}$ & Imprecision & $\begin{array}{c}\text { Publication } \\
\text { biases }\end{array}$ & $\begin{array}{l}\text { Effect of } \\
\text { the type of } \\
\text { brackets - } \\
\text { number of } \\
\text { bacteria }\end{array}$ & $\begin{array}{c}\text { Type of } \\
\text { bacterial } \\
\text { count }\end{array}$ & $\begin{array}{l}\text { General } \\
\text { quality }\end{array}$ \\
\hline $\begin{array}{l}\text { Pellegrini } \\
\text { et al., 2009[17] }\end{array}$ & $\sqrt{ }$ & $\sqrt{ }$ & $\sqrt{ }$ & $\sqrt{ }$ & $\sqrt{ }$ & $\sqrt{ }$ & $\sqrt{ }$ & $\sqrt{ }$ & ++++ \\
\hline $\begin{array}{l}\text { Pandis } \\
\text { et al., 2010[14] }\end{array}$ & $\begin{array}{l}\mathrm{X}=\text { division } \\
\text { in groups } \\
\text { to compare } \\
\text { brackets } \\
\text { and not in } \\
\text { split-mouth }\end{array}$ & $\begin{array}{l}\text { X=salivary } \\
\text { sample, } \\
\text { while other } \\
\text { studies used } \\
\text { the tooth }\end{array}$ & $\sqrt{ }$ & $\sqrt{ }$ & $\sqrt{ }$ & $\sqrt{ }$ & $\sqrt{ }$ & $\sqrt{ }$ & +++ \\
\hline $\begin{array}{l}\text { Hassan } \\
\text { et al., 2010[16] }\end{array}$ & $\sqrt{ }$ & $\sqrt{ }$ & $\sqrt{ }$ & $\sqrt{ }$ & $\sqrt{ }$ & $\sqrt{ }$ & $\sqrt{ }$ & $\sqrt{ }$ & ++++ \\
\hline $\begin{array}{l}\text { Baka } \\
\text { et al., 2013[13] }\end{array}$ & $\sqrt{ }$ & $\sqrt{ }$ & $\sqrt{ }$ & $\begin{array}{l}X=\text { lack of total } \\
\text { bacterial count, } \\
\text { parameter } \\
\text { used in the } \\
\text { other studies }\end{array}$ & $\sqrt{ }$ & $\sqrt{ }$ & $\sqrt{ }$ & $\sqrt{ }$ & +++ \\
\hline $\begin{array}{l}\text { Mummolo } \\
\text { et al., 2013[15] }\end{array}$ & $\begin{array}{l}\text { X=division } \\
\text { in groups } \\
\text { to compare } \\
\text { brackets } \\
\text { and not in } \\
\text { split-mouth }\end{array}$ & $\begin{array}{l}\text { X=salivary } \\
\text { sample, } \\
\text { while other } \\
\text { studies used } \\
\text { the tooth }\end{array}$ & $\sqrt{ }$ & $\begin{array}{l}X=\text { lack of } \\
\text { total bacterial } \\
\text { count, } \\
\text { parameter } \\
\text { used in the } \\
\text { other studies }\end{array}$ & $\sqrt{ }$ & $\sqrt{ }$ & $\sqrt{ }$ & $\sqrt{ }$ & +++ \\
\hline
\end{tabular}

Grade factors $-\sqrt{ }$ : No serious limitations, $X$ : Serious limitation (or there is no great/moderate effects on sample, dose effect), unclear, it is not possible to assess the item based on the available information. For general quality of evidence - +: Very low, ++: Low, +++: Moderate, ++++: High

\section{DISCUSSION}

This systematic review of randomized clinical studies considered the available literature on S. mutans count in individuals under orthodontic treatment using conventional metallic brackets in comparison to self-ligating brackets. In this context, this research aimed to answer whether the choice of bracket influences the accumulation of bacterial biofilm during orthodontic treatment.

Some of the studies selected ${ }^{[13,14]}$ had similar results, but no statistical differences regarding $S$. mutans count between self-ligating and conventional metallic brackets while other studies ${ }^{[16,17]}$ showed lower count in self-ligating brackets. Different from the literature, ${ }^{[10,18]}$ none of the studies indicated greater bacterial accumulation in self-ligating brackets. Despite the similar results, the studies differed evidently in materials and methods. The difference in materials is represented by the higher sample size $(n=60)$ observed in one study, ${ }^{[15]}$ which may have influenced the difference in $S$. mutans count compared to the other studies with smaller samples (n between 14 and 32). ${ }^{[13,14,16,17]}$ In relation to the methods, the main differences consisted of the type of ligature used and the site for collection of bacterial samples.
Two studies used ligatures of elastomers and analyzed bacteria collected from the saliva, ${ }^{[14,15]}$ two studies used steel ligatures and analyzed bacteria collected from the dental surface, ${ }^{[13,16]}$ and one study used ligatures of elastomers and analyzed bacteria collected from the dental surface. ${ }^{[17]}$

More specifically, from the studies that analyzed bacterial samples from the dental surface, two ${ }^{[13,17]}$ performed the collection around brackets placed in lateral incisors. It was justified due to the high incidence of white lesions on enamel in these teeth, which is potentially associated with the close relation between the bracket and the gingiva. ${ }^{[13]} \mathrm{A}$ third study ${ }^{[16]}$ that analyzed bacteria from dental surface performed the collection adjacent to the canine gingival margin, trespassing $1 \mathrm{~mm}$ of the sulcus. However, the authors did not justify the reason for choosing this specific tooth and tooth region. The collection of bacterial samples from the saliva enabled the analysis of variation in the microbiota level potentially induced by the orthodontic appliances. However, the collection of bacterial samples from the saliva has disadvantages. The paraffin wax used to stimulate the salivary flow may detach the microbiota from dental surfaces, possibly interfering with the amount of bacteria found in the outcomes. ${ }^{[15]}$ 
Longoni, et al.: Streptococcus mutans adhesion on metallic brackets

\begin{tabular}{|c|c|c|c|c|c|}
\hline $\begin{array}{l}\text { Authorship } \\
\text { and year }\end{array}$ & Baka et al., 2013 & Hassan et al., 2010[16] & $\begin{array}{l}\text { Mummolo } \\
\text { et al., 2013 }\end{array}$ & Pandis et al., 2010[14] & $\begin{array}{l}\text { Pellegrini } \\
\text { et al., 2009[17] }\end{array}$ \\
\hline Country & Turkey & Saudi Arabia & Italy & Greece & USA \\
\hline $\begin{array}{l}\text { Sample } \\
\text { number and } \\
\text { gender }\end{array}$ & 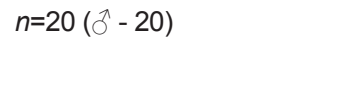 & $n=22(\lesssim-12 \mid+-10)$ & 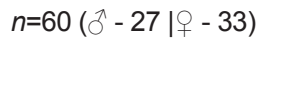 & $n=32^{\bullet}$ & $n=14^{*}(\hat{\jmath}-5 \mid q-9)$ \\
\hline $\begin{array}{l}\text { Ages of } \\
\text { patients }\end{array}$ & $\begin{array}{l}11.0 \text { and } 16.7 \text { years } \\
\text { (average of } 14.2 \pm 1.5 \text { ) }\end{array}$ & $\begin{array}{l}13 \text { and } 22 \text { years } \\
\text { (average of } 17.1 \text { years) }\end{array}$ & $\begin{array}{l}18 \text { and } 23 \text { years } \\
\text { (average of } 20.5 \pm 1.62 \text { ) }\end{array}$ & $\begin{array}{l}11 \text { and } 17 \text { years } \\
\text { (average of } 13.6 \text { years) }\end{array}$ & $\begin{array}{l}11.7- \\
17.2 \text { years (average } \\
\text { of } 13.9 \text { years) }\end{array}$ \\
\hline $\begin{array}{l}\text { Study } \\
\text { design }\end{array}$ & $\begin{array}{l}\text { Quasi-randomized } \\
\text { controlled } \\
\text { split-mouth trials }\end{array}$ & $\begin{array}{l}\text { Quasi-randomized } \\
\text { controlled } \\
\text { split-mouth trials }\end{array}$ & $\begin{array}{l}\text { Randomized } \\
\text { controlled trials }\end{array}$ & $\begin{array}{l}\text { Quasi-randomized } \\
\text { controlled trials }\end{array}$ & $\begin{array}{l}\text { Quasi-randomized } \\
\text { controlled } \\
\text { split-mouth trials }\end{array}$ \\
\hline $\begin{array}{l}\text { System } \\
\text { and type } \\
\text { of ligature }\end{array}$ & $\begin{array}{l}\text { In-ovation R - GAC } \\
\text { (active)|mini-ovation - GAC } \\
\text { (elastomeric ligature) }\end{array}$ & $\begin{array}{l}\text { In-ovation R - GAC } \\
\text { (active)|microarch - GAC } \\
\text { (elastomeric ligature) }\end{array}$ & $\begin{array}{l}\text { Damon } 3 \text { - Ormco } \\
\text { (passive) } \mid \Omega \\
\text { (stain-less ligature) }\end{array}$ & $\begin{array}{l}\text { Damon Q - Ormco } \\
\text { (passive)|roth } \\
\text { equilibriun } \\
2 \text { - dentaurum } \\
\text { (stain-less ligature) }\end{array}$ & $\begin{array}{l}\text { In-ovation - GAC } \\
\text { (active)|ovation - GAC } \\
\text { (elastomeric ligature) }\end{array}$ \\
\hline Slots size & $\begin{array}{l}\text { Both with } 0.022 \\
\text { inch } \times 0.025 \text { inch slots }\end{array}$ & $\Omega$ & $\begin{array}{l}\text { Straight wire } \\
\text { appliances with } 0.018 \\
\text { inch and self-ligature } \\
\text { with } 0.022 \text { inch } \times \\
0.025 \text { inch slots }\end{array}$ & $\begin{array}{l}\text { Both with } 0.022 \\
\text { inch } \times 0.025 \text { inch slots }\end{array}$ & $\Omega$ \\
\hline $\begin{array}{l}\text { Type of } \\
\text { ligature }\end{array}$ & Steel ligature & Steel ligature & Elastomer & Elastomer & Elastomer \\
\hline $\begin{array}{l}\text { Dental arch } \\
\text { involved }\end{array}$ & Split mouth & Split mouth & Whole mouth & Whole mouth & Split mouth \\
\hline $\begin{array}{l}\text { Collection } \\
\text { site }\end{array}$ & $\begin{array}{l}\text { Maxillary and mandibular } \\
\text { lateral incisors, buccal } \\
\text { surface of teeth }\end{array}$ & $\begin{array}{l}\text { Canines, mesial and } \\
\text { distal, trespassing } 1 \\
\mathrm{~mm} \text { of gingival sulcus }\end{array}$ & Salivary sample & Salivary sample & $\begin{array}{l}\text { Maxillary and } \\
\text { mandibular lateral } \\
\text { incisors, around } \\
\text { brackets }\end{array}$ \\
\hline $\begin{array}{l}\text { Collection } \\
\text { frequency }\end{array}$ & $\begin{array}{l}\mathrm{T} 0=\text { Before bonding } \\
\mathrm{T} 1=\text { Periodontal } \\
\text { assessment only } \\
\mathrm{T} 2=3^{\text {rd }} \text { week after bonding }\end{array}$ & $\begin{array}{l}\mathrm{T} 0=\text { before bonding } \\
\mathrm{T} 1=1^{\text {st }} \text { week } \\
\text { after bonding } \\
\mathrm{T} 2=4^{\text {th }} \text { week } \\
\mathrm{T} 3=12^{\text {th }} \text { week } \\
\mathrm{T} 4=24^{\text {th }} \text { week }\end{array}$ & $\begin{array}{l}\mathrm{T} 0=\text { before bonding } \\
\mathrm{T} 1=12^{\text {th }} \text { week } \\
\text { after bonding } \\
\mathrm{T} 2=24^{\text {th }} \text { week }\end{array}$ & $\begin{array}{l}\text { T0 before bonding } \\
\text { T1=2-3 months } \\
\text { after bonding }\end{array}$ & $\begin{array}{l}\mathrm{T} 0=\text { before bonding } \\
\mathrm{T} 1=1^{\text {st }} \text { week } \\
\text { after bonding } \\
\mathrm{T} 2=5^{\text {th }} \text { week }\end{array}$ \\
\hline $\begin{array}{l}\text { Storage } \\
\text { solution }\end{array}$ & $\begin{array}{l}\text { In sterile Eppendorf } \\
\text { tubes, with sterile } \\
\text { phosphate-buffered } \\
\text { saline solution, and } \\
\text { stored at }-80^{\circ} \mathrm{C}\end{array}$ & $\begin{array}{l}\text { In vials, with nitrogen } \\
\text { until the laboratory. } \\
\text { In plates with blood } \\
\text { agar for total bacteria } \\
\text { and Mitis Salivarius } \\
\text { agar with } 0.001 \% \\
\text { Chapman Tellurite } \\
\text { solution (Difco), } 150 \mathrm{~g} \\
\text { of sucrose, and } 3.33 \\
\text { mg of bacitracin per liter }\end{array}$ & $\begin{array}{l}\text { In agar plates selective } \\
\text { for Streptococcus } \\
\text { mutans, incubated } \\
\text { at } 37^{\circ} \mathrm{C} \text { for } 2 \text { days in } \\
\text { a } \mathrm{CO}_{2} \text { atmosphere } \\
\text { (CRT incubator) after } \\
\text { adding } \mathrm{NaHCO}_{3} \text { tablet }\end{array}$ & $\begin{array}{l}\text { In Petri plates: } \\
\text { nonselective - with } \\
\text { blood agar and } \\
\text { supplemented with } \\
7 \% \text { sterile blood; } \\
\text { selective - Mitis } \\
\text { Salivarius agar } \\
\text { supplemented } \\
\text { with } 20 \% \text { sucrose, } \\
\text { bacitracin, and } \\
\text { tellurite solution }\end{array}$ & $\begin{array}{l}\text { In plates and saliva: } \\
\text { phosphate-buffered } \\
\text { saline solution, } \\
\text { washed with enriched } \\
\text { blood agar, and } \\
\text { limiting dilution in Mitis } \\
\text { Salivarius agar plates }\end{array}$ \\
\hline $\begin{array}{l}\text { Type of } \\
\text { analysis }\end{array}$ & $\begin{array}{l}\text { Real-time PCR analysis, } \\
\text { with Lightcycler TaqMan } \\
\text { master mix, of DNA } \\
\text { extracted from bacteria }\end{array}$ & $\begin{array}{l}\text { Stereomicroscopic } \\
\text { reading and } \\
\text { colony-forming units } \\
\text { expressed by } \mathrm{ml} \\
(\mathrm{CFU} / \mathrm{ml})\end{array}$ & $\begin{array}{l}\text { Count based on } \\
\text { colony staining } \\
\text { through the CRT } \\
\text { bacteria test from } \\
\text { Ivoclar Vivadent, } \\
\text { Inc., counting was } \\
\text { performed (CFU/ml) }\end{array}$ & $\begin{array}{l}\text { Count based on colony } \\
\text { morphology, Gram } \\
\text { staining, and catalase } \\
\text { activity. From these, } \\
\text { representative colonies } \\
\text { were replicated and } \\
\text { biochemical tests were } \\
\text { performed. Count } \\
\text { expressed in CFU/ml }\end{array}$ & $\begin{array}{l}\text { Measurement } \\
\text { by ATP-driven } \\
\text { bioluminescence, } \\
\text { using luciferin } \\
\text { substrate and } \\
\text { luciferase enzyme. } \\
\text { Bacterial ATP } \\
\text { measured by the } \\
\text { RLUs }\end{array}$ \\
\hline
\end{tabular}

-No gender distinction; ${ }^{\wedge}$ : Men,, : Women, T0: Before bonding and T1, T2, T3: After bonding. ${ }^{¥} 14$ patients (maxilla and mandible) and two patients
(maxilla only). $\Omega$ : Not informed, CFU: Colony-forming units, RLUs: Relative light unit, PCR: Polymerase chain reaction, ATP: Adenosine triphosphate,
CRT: Caries risk test, GAC Orthomax, Dentsply, São Paulo, Brazil

The initial amount of $S$. mutans has a significant effect on the bacterial count throughout time, which features a specific risk factor to the patient. ${ }^{[14]}$ Based on that, the literature does not recommend the use of ligatures of elastomers in patients with poor oral hygiene. ${ }^{[6,17]}$ One of the eligible studies ${ }^{[17]}$ showed that self-ligating brackets had less bacterial retention in the period between 1 and 5 weeks after bonding 
compared to the conventional brackets. This finding was corroborated by another study ${ }^{[16]}$ that assessed the bacterial colonization at 1, 4, 12, and 24 weeks after the bonding of brackets through stereomicroscopic reading. In opposite, another study ${ }^{[14]}$ found no difference at 2-3 weeks after bonding. Differently, one of the studies ${ }^{[13]}$ used in this systematic review assessment the amount of bacteria with real-time PCR analysis, 3 months after installation of brackets. These authors notice that the increase in the amount of bacteria after the installation of orthodontic brackets was similar in both systems and had no statistically significant differences. The study by Mummolo et al., ${ }^{[15]}$ in turn, observed the bacterial accumulation using caries risk test (CRT) bacteria test (Ivoclar Vivadent Inc., Barueri, Brazil) in a period between 12 and 24 weeks after bonding of brackets. In their study, the amount of bacteria was associated with time and type of bracket used. The specific heterogeneity in the materials and methods of the eligible studies discussed in this systematic literature review apparently does not influence the outcomes, once similar results were observed.

Other aspects that potentially influence the amount of bacterial accumulation in orthodontic brackets are the type of adhesives and composites used for bonding. ${ }^{[24,25]}$ Adhesives may influence the level of bacterial adherence depending on their types and brands. Currently, adhesives that promote less accumulation are available and indicated for daily clinical use. ${ }^{[9]}$ Composites are often discussed in the face of their roughness (size of their particles). However, the composite surface area exposed in the oral environment plays a more significant role for biofilm accumulation. ${ }^{[2]}$ The studies considered eligible in this systematic literature review did not consider or discuss these aspects, which represents a major methodological limitation.

Apart the limitations observed within the eligible articles, the present systematic literature review also faced potential pitfalls. Several aspects that could influence on bacterial adhesion were observed and explored, such as the type of brackets, ligatures and adhesives. However, other aspects remained unfeasible for a more detailed analysis, such as the different brands, systems and slot sizes used for orthodontic treatment. In specific, information on these aspects was extracted from the scientific literature [Table 4] but not explored in detail because of the high variation (in brands, systems and slot sizes) within only five eligible articles. It is expected that such stratified analysis would be feasible in the feature with more articles eligible.

Based on the exposed, the clinical importance of this research is related to the effects of the use of orthodontic appliances in oral tissues. According to the data and results presented, bracket systems are associated with bacterial accumulation depending on their type. Self-ligating brackets trend to accumulate less biofilm (especially involving $S$. mutans). This outcome may influence the orthodontist decision for choosing appliances in their clinical routine. New studies with more standardized methods are necessary to enhance the scientific evidence and to provide more assertive conclusions on the topic. In the meantime, the incentive for oral hygiene maintenance through detailed instruction of patients should be considered to minimize the bacterial accumulation in orthodontic brackets.

The outcomes presented should be interpreted in conjunction with particularities of each patient, such as oral hygiene and dietary habits since the $S$. mutans needs a multifactorial environment to proliferate and keeps retained. The evidence related to $S$. mutans retention by orthodontic brackets should be improved through further randomized clinical studies. These studies should attempt to report the bacterial count at the baseline; using completely blind participants and investigators about the condition concerned; with truly randomized assignment to treatment groups; and avoiding patients randomized from a unique service (exclusively from one professional). In this context, a multicenter study should be encouraged.

\section{CONCLUSION}

Self-ligating brackets accumulate less S. mutans than conventional metallic brackets. However, this conclusion should be interpreted with caution due to the limited availability of evidence.

\section{Financial support and sponsorship \\ Nil.}

\section{Conflicts of interest}

There are no conflicts of interest.

\section{REFERENCES}

1. Ousehal L, Lazrak L, Es-Said R, Hamdoune H, Elquars F, Khadija A. Evaluation of dental plaque control in patients wearing fixed orthodontic appliances: A clinical study. Int Orthod 2011;9:140-55.

2. Gwinnett AJ, Ceen RF. Plaque distribution on bonded brackets: a scanning microscope study. Am J Orthod 1979;75:667-77. 
3. Mota SM, Enoki C, Ito IY, Elias AM, Matsumoto MA. Streptococcus mutans counts in plaque adjacent to orthodontic brackets bonded with resin-modified glass ionomer cement or resin-based composite. Braz Oral Res 2008;22:55-60.

4. Bhagchandani J, Singh AK, Mehrotra P, Shashi Kumar HC, Varshney SR, Varshney KR. Microbial colonization around orthodontic ligature ties: An in vivo study. APOS Trend Orthod 2013;3:72-7.

5. Corghi RG, Malavazi DF, Quintela MM, Aquino DR, da Silva HG, Roman-Torres CV. Evaluation of periodontal clinical parameters of patients with orthodontic appliances with conventional and self-ligating brackets. Braz J Periodontol 2014;24:30-4.

6. Pradeep S. Determination of microbiological flora of different hygienic ligatures techniques - An in vivo study. Int J Curr Microbiol Appl Sci 2014;3:739-46.

7. Türkkahraman H, Sayin MO, Bozkurt FY, Yetkin Z, Kaya S, Onal S. Archwire ligation techniques, microbial colonization, and periodontal status in orthodontically treated patients. Angle Orthod 2005;75:231-6.

8. Benson PE, Douglas CW, Martin MV. Fluoridated elastomers: Effect on the microbiology of plaque. Am J Orthod Dentofacial Orthop 2004;126:325-30.

9. Velazquez-Enriquez U1, Scougall-Vilchis RJ, Contreras-Bulnes R, Flores-Estrada J, Uematsu S, Yamaguchi R. Quantitative analysis of S. mutans and S. sobrinus cultivated independently and adhered to polished orthodontic composite resins. J Appl Oral Sci 2012;20:544-9.

10. van Gastel J, Quirynen M, Teughels W, Pauwels M, Coucke W, Carels C. Microbial adhesion on different bracket types in vitro. Angle Orthod 2009;79:915-21.

11. do Nascimento LE, Pithon MM, dos Santos RL, Freitas AO, Alviano DS, Nojima LI, et al. Colonization of Streptococcus mutans on esthetic brackets: Self-ligating vs. conventional. Am J Orthod Dentofacial Orthop 2013;143 4 Suppl:S72-7.

12. Da Silva LJ, Mattos FS, da Silva MG, Araújo AM, Werneck EC. Determination of microorganisms found in Alexander's and self-ligating brackets. Ortodont SPO 2010;43:227-34.

13. Baka ZM, Basciftci FA, Arslan U. Effects of 2 bracket and ligation types on plaque retention: A quantitative microbiologic analysis with real-time polymerase chain reaction. Am J Orthod Dentofacial Orthop 2013;144:260-7.
14. Pandis N, Papaioannou W, Kontou E, Nakou M, Makou M, Eliades T. Salivary Streptococcus mutans levels in patients with conventional and self-ligating brackets. Eur J Orthod 2010;32:94-9.

15. Mummolo S, Marchetti E, Giuca MR, Gallusi G, Tecco S, Gatto R, et al. In-office bacteria test for a microbial monitoring during the conventional and self-ligating orthodontic treatment. Head Face Med 2013;9:7.

16. Hassan KS, Alagl AS, Ali I. Periodontal status following self-ligature versus archwire ligation techniques in orthodontically treated patients - Clinical, microbiological and biochemical evaluation. Orthod Waves 2010;69:164-70.

17. Pellegrini P, Sauerwein R, Finlayson T, McLeod J, Covell DA Jr., Maier $\mathrm{T}$, et al. Plaque retention by self-ligating vs. elastomeric orthodontic brackets: Quantitative comparison of oral bacteria and detection with adenosine triphosphate-driven bioluminescence. Am J Orthod Dentofacial Orthop 2009;135:426.e1-9.

18. Pithon MM, Santos RL, Nascimento LE, Ayres AO, Alviano D, Bolognese AM. Do self-ligating brackets favor greater bacterial aggregation? Braz J Oral Sci 2011;10:208-12.

19. Moher D, Liberati A, Tetzlaff J, Altman DG; PRISMA Group. Preferred reporting items for systematic reviews and meta-analyses: The PRISMA statement. Int J Surg 2010;8:336-41.

20. Deeks J, Gatsonis C. Cochrane Handbook for Systematic Reviews of Diagnostic Test Accuracy. The Cochrane Collaboration; 2015.

21. PROSPERO. International Prospective Register of Systeatic Reviews. University of York: Centre for Reviews and Dissemination; 2016.

22. The Joanna Briggs Institute. Joanna Briggs Institute Reviewers' Manual. The Joanna Briggs Institute; 2014.

23. Schünemann H, Brożek J, Guyatt G, Oxman A. GRADE Handbook for Grading Quality of Evidence and Strength of Recommendations. The GRADE Working Group; 2013.

24. Alkis H, Turkkahraman H, Adanir N. Microleakage under orthodontic brackets bonded with different adhesive systems. Eur J Dent 2015;9:117-21.

25. Buyuk SK, Cantekin K, Demirbuga S, Ozturk MA. Are the low-shrinking composites suitable for orthodontic bracket bonding? Eur J Dent 2013;7:284-8.

\begin{tabular}{lll}
\multicolumn{2}{l}{ Appendix 1: Articles excluded and the reasons for exclusion $(n=3)$} & Reasons for exclusion \\
\hline Reference & Author & 1 \\
\hline$[1]$ & Folco et al. $(2014)^{[1]}$ & 2 \\
{$[2]$} & Pejda et al. $(2013)^{[2]}$ & 1
\end{tabular}

\section{References}

Folco AA, Benítez-Rogé SC, Iglesias M, Calabrese D, Pelizardi C, Rosa A, et al. Gingival response in orthodontic patients: Comparative study between self-ligating and conventional brackets. Acta Odontol Latinoam 2014;27:120-4

Pejda S, Varga ML, Milosevic SA, Mestrovic S, Slaj M, Repic D, et al. Clinical and microbiological parameters in patients with self-ligating and conventional brackets during early phase of orthodontic treatment. Angle Orthod 2013;83:133-9

Pandis N, Vlachopoulos K, Polychronopoulou A, Madianos P, Eliades T Periodontal condition of the mandibular anterior dentition in patients with conventional and self-ligating brackets. Orthod Craniofac Res 2008;11:211-5

1: The study performed only periodontal assessment without quantification of bacteria, 2: The study performed only periodontal assessment with emphasis in sub gingival bacteria and without quantification of Streptococcus mutans 


\begin{tabular}{|c|c|c|c|c|c|}
\hline \multicolumn{6}{|c|}{$\begin{array}{l}\text { Appendix 2: Risk of bias assessed by Meta analysis of Statistics Assessment and Review Instrument critical } \\
\text { appraisal tools for randomized and quasi-randomized controlled trials }\end{array}$} \\
\hline \multirow[t]{2}{*}{ Question } & \multicolumn{5}{|c|}{ Answer } \\
\hline & $\begin{array}{l}\text { Baka et al., } \\
2013^{[13]}\end{array}$ & $\begin{array}{l}\text { Hassan } \\
\text { et al., 2010 }\end{array}$ & $\begin{array}{l}\text { Mummolo } \\
\text { et al., 2013 }\end{array}$ & $\begin{array}{l}\text { Pandis et al., } \\
\text { 2010 }\end{array}$ & $\begin{array}{l}\text { Pellegrini } \\
\text { et al., 2009[17] }\end{array}$ \\
\hline 1. Is the assignment to treatment groups truly random? & $\mathrm{U}$ & $\mathrm{Y}$ & $\mathrm{U}$ & $\mathrm{U}$ & $\mathrm{U}$ \\
\hline 2. Are participants blinded to treatment allocation? & $\mathrm{Y}$ & Y & Y & $\mathrm{Y}$ & $\mathrm{N}$ \\
\hline $\begin{array}{l}\text { 3. Is allocation to treatment groups } \\
\text { concealed from the allocator? }\end{array}$ & $\mathrm{N}$ & $\mathrm{N}$ & $\mathrm{Y}$ & $\mathrm{Y}$ & $U$ \\
\hline $\begin{array}{l}\text { 4. Are the outcomes of people who withdrew } \\
\text { described and included in the analysis? }\end{array}$ & $U$ & $U$ & $U$ & Y & Y \\
\hline $\begin{array}{l}\text { 5. Are those assessing the outcomes } \\
\text { blind to the treatment allocation? }\end{array}$ & Y & Y & $\mathrm{Y}$ & Y & Y \\
\hline 6. Are the control and treatment groups comparable at entry? & $\mathrm{N}$ & $\mathrm{N}$ & Y & $\mathrm{N}$ & $\mathrm{N}$ \\
\hline $\begin{array}{l}\text { 7. Are groups treated identically other } \\
\text { than for the named intervention? }\end{array}$ & Y & Y & Y & Y & Y \\
\hline 8. Are outcomes measured in the same way for all groups? & Y & Y & Y & Y & Y \\
\hline 9. Are outcomes measured in a reliable way? & Y & Y & $\mathrm{Y}$ & Y & $\mathrm{Y}$ \\
\hline 10. Is appropriate statistical analysis used? & $\mathrm{Y}$ & $\mathrm{Y}$ & Y & $\mathrm{Y}$ & Y \\
\hline Percentage of yes/risk & 60 & 70 & 80 & 80 & 60 \\
\hline
\end{tabular}

Risk of bias was categorized as high when the study reaches up to $49 \%$ score "yes," moderate when the study reached $50 \%-69 \%$ score "yes," and low when the study reached more than $70 \%$ score "yes." Y: Yes, N: No, U: Unclear 